\title{
IMPLEMENTATION OF TENTARA MANUNGGAL MEMBANGUN DESA PROGRAMS TO ACHIEVE FOOD SECURITY IN DISTRICT OF GRESIK
}

\author{
Setyadi Hendro, Wijoyo Suparto \\ Postgraduate School, University of Airlangga, Indonesia \\ *E-mail: setyadihendro730@gmail.com
}

\begin{abstract}
The complexity of food security development with the various constraints requires a crosssectoral approach and partnership at the national, regional, and district/city levels. The involvement of the TNI-AD (Army) in supporting national development priorities to achieve food self-sufficiency is encouraged by the President of the Republic of Indonesia. The purpose of this study is to analyze the principles of national and regional food security in Indonesia and the form of cooperation and implementation of the "TNI Manunggal Membangun Desa" to realize food security in Gresik Regency. This study is observational through the discussion forum and document study. The results indicate that during the implementation of "TNI Manunggal Membangun Desa" program since 2012 has been achieved development that supports food security such as the development of village embung, village barns, farm roads, agricultural irrigation, and other supporting infrastructure to empower communities in the management of major food agriculture.
\end{abstract}

\section{KEY WORDS}

Food security, Tentara Manunggal Membangun Desa program, agricultural village, public service.

The State shall be obliged to realize the availability, affordability, and fulfilment of adequate, safe, quality and balanced nutritious food consumption both national, regional, and personal evenly throughout the territory of the Unitary State of the Republic of Indonesia at all times by utilizing resources, institutions and culture local. Considering the obligation, Law No. 18 of 2012 on Food mandates the implementation of food as a form of planning, implementation and supervision activities in the provision, affordability, fulfilment of food, nutrition, and food security by involving the coordinated and integrated community participation in order to fulfil basic human needs that provide benefits equitably, evenly and sustainably based on Food Sovereignty, Food Self-Reliance, and Food Security (Maxwell, 1992).

Reviewing national development planning based on Presidential Regulation No. 29 of 2014 National Medium Term Development Plan (RPJMN) 2015-2019 has set priority development goals in realizing production security for self-reliance and diversification of food consumption.

In line with the dimension of food security development, efforts to achieve food security must be supported through the role of various development stakeholders who must contribute in an integrative way, synergize in managing resources, and play a real role in implementing food security programs (Infid, 2015). One of the stakeholders of food security development that has contributed widely is the Army through a territorial assistance program implemented in the scope of the district/city.

The involvement of the Indonesian Army in supporting the national development priority to achieve self-sufficiency in food is encouraged by the President of the Republic of Indonesia as presented to the participants of the Central Dandim-Danrem Meeting on December 2nd, 2014, in Sulung Village, South Arut Subdistrict, Kotawaringin Barat, Central Kalimantan. In the meeting, the President instructed Army officers, Danrem, Dandim, Pangdam, to assist the burden of the duty of the city, district, province and ministry, especially in achieving food self-sufficiency. 
This presidential instruction was welcomed by the Minister of Agriculture to invite the TNI-AD especially Bintara Pembina Desa (Babinsa) to engage in agricultural extension and oversee local food security. This cooperation was welcomed by TNI-AD as explained by Kapuspen TNI Maj. Gen. Fuad Basya that the TNI will deploy the Babinsa as agricultural extension agents and motivate the farmers to accelerate the process of achieving national food security at the Centralized Unit Commander Apples in 2014 in Pangkalan Bun, Central Kalimantan 2-5 December 2014 (Puspen TNI, 2014).

\section{METHODS OF RESEARCH}

This study is observational through the discussion forum and document study. The approach used in this research is socio-legal. The socio-legal approach is a combination of approaches within the social sciences, including political, economic, cultural, historical, anthropological, communications and other sciences combined with a recognized approach to law, such as learning about principles, doctrines and hierarchy of legislation. This research was conducted through observation of KODIM 0817/Gresik and Government of Gresik Regency in this case related Device during the implementation of TNI Manunggal Membangun Desa program. The data collection is done through interviews and reviewing the administrative documents produced during the implementation of TNI Manunggal Membangun Desa program.

\section{RESULTS AND DISCUSSION}

The National Medium Term Development Plan (RPJMN) 2015-2019 prioritizes the improvement of food sovereignty as one of the priority sub-agendas to realize the national development agenda of economic independence by mobilizing the strategic sectors of the domestic economy. In order to improve and strengthen food sovereignty, the general policy in the RPJMN 2015-2019 is directed at: (1) strengthening food security towards food selfsufficiency by increasing staple food production; (2) stabilization of food prices; (3) improving the quality of food consumption and community nutrition; (4) mitigation of disruption to food security; and (5) improvement of prosperity of food business actors. In line with the RPJMN's general policy, the Ministry of Agriculture as the main stakeholder in the framework of strengthening food security. It focuses on improving the strategic staple food production and other agricultural commodities to meet domestic food needs as contained in the Strategic Plan of the Ministry of Agriculture 2015-2019. Strengthening food security, it's must be based on independence and food sovereignty supported by subsystems of availability, distribution and consumption of integrated food. The achievement of steady food security is a vehicle for strengthening economic and political stability and ensuring the availability of food at affordable prices (Wiesma, 2000).

In line with the national priorities, the development of food sovereignty development, food self-sufficiency and food security in the province of Java East Java has become one of the regional strategic issues as contained in Regional Regulation of East Java Province No. 1 of 2017 on the amendment of Regional Regulation of East Java No 3 of 2014 About East Java Medium-Term Development Plan of 2014-2019, it states that rice dependence as staple food commodity is still high (Ariani, 2003) while society consumption pattern is not yet diverse, nutritious, balanced and safe although East Java has wide of rice field of $1.017549,73$ hectare and distribution of potential utilization that manifested in the form of food commodity surplus of 4.48 million tons of rice. In more detail, the target of food sovereignty development as one of the leading sectors of East Java is targeted by realizing the availability of food covering of 9,035,000 tons of rice, 6.5 million tons of corn, and 360,000 tons of soybeans. The growth of subcategory of a plantation to Gross Regional Domestic Product (PDRB) reaches 2,25-308\%, the growth of livestock subcategory to PDRB reach $2,94 \%$, while the growth of subcategory of the fishery to PDRB reaches $5,3 \%$ in the year 2019. 
The availability of primary food in the region in order to achieve the independence of sovereignty and national food security is one of the main agenda of national development and East Java Province. In harmony with this, the development of Food Sovereignty, Food Self-Reliance, and Food Security is also one of the priorities of Gresik Regency development. As stated in the Regional Regulation of Gresik Regency No.10 of 2017 regarding the Amendment of Regional Regulation of Gresik Regency No.09 of 2016 regarding Regional Medium Term Development Plan (RPJMD) 2016-2021 that the strategic issue of food security in terms of the availability of main food per capita per year. In the year 2013 to 2014 decreased the availability of food to be $176.36 \mathrm{~kg} /$ capita/year. While the year 2016 increased to reach 202,21 kg / capita / Year. By 2017, the main food availability ratio increased significantly to $300.84 \mathrm{~kg} /$ capita/year.

The decline in the availability of primary food is not a single indicator that affects the achievement of regional food self-sufficiency but there is still food insecurity, food diversification, and the area of crop production (Nuhfill, 2012). In terms of food insecurity, Gresik Regency does not yet have an optimal food insecurity mitigation system without the availability of food insecurity maps although the supporting infrastructure of agricultural production has been built and developed during 2011-2017. The mastery of adaptive cultivation technology to climate change is still not implemented while the conventional agricultural culture still dominates. In addition, the welfare of farmers and farm labourers who are still left behind by the lack of standard and added value that raised the living standard of farmers and farm workers, although agriculture gives the second largest contribution in GRDP Gresik Regency.

Food expectation is a diverse array of foods based on major food group energy contributions (both absolute and from a pattern of availability and/or food consumption). In the context of diversification of main food consumption, indicated by the level of caloric consumption in 2014 reached $91.32 \mathrm{~kg} / \mathrm{capita} / \mathrm{year}$. This achievement continues to decrease when compared with the level of caloric consumption in 2012 which reached 95.40 $\mathrm{kg} /$ capita/year. In the case of plotting area or agricultural land, it is explained that the area of Sustainable Agriculture Farming Area (LP2B) as stipulated is $24.716 \mathrm{Ha}$ and spread throughout the Regency of Gresik, the extent is based on the study of the determination of area and delineation maps. On the other hand, the area of Sustainable Agricultural Reserve Land is set as wide as 3,005 Ha and spread throughout the Regency of Gresik, the extent is based on the study of area determination and delineation map. The establishment of LP2B is aimed at the field of agricultural land that is set to be protected and developed consistently to produce basic food for national food self-sufficiency, resilience and sovereignty.

The cooperation between Ministry of Agriculture and TNI in realizing food security has been stated in the Memorandum of Understanding between the Minister of Agriculture of the Republic of Indonesia and the Commander of the TNI No. 03 / MoU / PP.310 / M / 4/2012 and NK / 8 / IV / 2012 on April 132012 on cooperation to realize national food security. Furthermore, both parties through the Directorate General of Preparation and Agriculture Facility of the Ministry of Agriculture and the Armed Forces have signed a Cooperation Agreement No. 836 / RC.120 / 11/2012 and KERMA / 9XI / 2012 on 30 November 2012 on Cooperation Program in support of increasing food security which ends on 31 December 2013. In 2014, the Directorate General of Preparation and Facility of Agriculture of the Ministry of Agriculture and the Army again agreed to cooperate on the Cooperation Program to Support Food Security Enhancement on January 29, 2014, in Jakarta.

In order to support the national development priority to achieve food security and the commitment of TNI-AD in supporting the task of governance, KODIM 0817/ GRESIK cooperates with the government of Gresik Regency to initiate the program of territorial assistance to be more optimal in developing of food security. One of the TNI AD assistance program in terms of KODIM 0817 / GRESIK is the cooperation with government of Gresik Regency through the Department of Community Empowerment and Village of Gresik Regency (Dinpemas) to projected the development of food security through the program of unity army build the village or Tentara Manunggal Membangun Desa (TMMD). TMMD Program has been implemented in Gresik Regency since 2012 in 8 (eight) Villages and 8 
(eight) Districts such as Village Lundo (sub-district Benjeng), Cermelerek (Kedamean), Ngabetan (Cerme), Ngampel (Balongpanggang).

Based on the cooperation, the two sides agreed on the scope of cooperation include (1) Wetland expansion activities are undertaken on farmers' land beneficiaries of social assistance; (2). Land optimization activities carried out on the farmers' land as a beneficiaries of social assistance program; (3) Development activities of the method of System Rice of Intensification (SRI) implemented on the farmers' land of beneficiaries of social assistance program; (4) Planting Brigade activities carried out in order to support the acceleration of processing and simultaneous planting; and (5) Activities of water resources utilization infrastructure and facilities implemented in the farmers' lands of beneficiaries of social assistance.

Implementation of the Tentara Manunggal Membangun Desa program since 2012 has achieved development that supports food security such as the development of village embungs, village barns, farm roads, agricultural irrigation, and other supporting infrastructure to empower communities in the management of major food agriculture, horticulture, and medicine. It was in line with the concept of development mandated in Law Number 06 of 2014 on Village Article 83 that Rural Area Development is implemented in an effort to accelerate and improve the quality of service, development and empowerment of village communities in Rural Areas through participatory development approach.

Although it has made a tangible contribution, implementation of the program meet various obstacles in realizing food security entirely include: (1) agricultural land is increasingly limited due to efforts to expand agricultural areas more difficult while conversion of productive agricultural land to other agricultural and non-agricultural continue to occur; (2) the availability of water resources to support reduced food production as a result of damage to the watershed ecosystem (DAS) and competition for water use for other sector needs, and damage to irrigation networks. The achievement of the program has not been optimal includes the development of food security in rural areas.

\section{CONCLUSION}

Tentara Manunggal Membangun Desa Program is a form of commitment and cooperation between TNI-AD and local government to realize food security in the local sphere. This cooperation is realized as a mentoring of the territory of Gresik under KODIM 0817 / GRESIK which is held every 2 (two) years. This program supports the achievement of several aspects of food security such as the development of village barns, farm roads, agricultural irrigation, and other supporting infrastructure to empower communities in the management of agriculture. However, this program has not optimally supported overall food security dimension due to the scope of the program that is not widespread, limited agricultural land, and water resources. Although not yet optimal, the Tentara Manunggal Membangun Desa Program is one of the best practices for the empowerment of village communities in the Rural Areas through a participatory development approach.

\section{REFERENCES}

1. Ariani, M. and Rachman, H.P.S., 2003. Analisis Tingkat Ketahanan Pangan Rumah Tangga. Media Gizi and Keluarga. 27 (2). 1-6.

2. Hanani, Nuhfil., 2012. Strategi Pencapaian Ketahanan Pangan Keluarga, Perhimpunan Ekonomi Pertanian Indonesia, Bogor.

3. International NGO Forum on Indonesian Development (INFID) 2015. Outcome Document Transforming Our World: The 2030 Agenda For Sustainable Development. INFID.

4. Maxwell, 1992. Household Food Security Concepts, Indicator, and Measurement. IFAd.

5. Puspen TNI., 2014. Keterangan Pers Apel Komandan Satuan secara Terpusat (Dansat) tahun 2014 di Pangkalan Bun, Kalimantan Tengah 2-5 Desember 2014.

6. Wiesma.,D., L. Weingartner, Schoninger. 2000. The Challenge of Hunger: Global Hunger Index: Fact, Determinant, And Trend: Deutsche Wlthugerhilfe: Washington DC. 